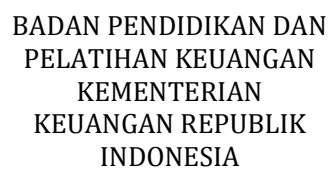

\title{
ANALISIS PENGARUH DIMENSI BRAND IMAGE TERHADAP BRAND IMAGE DAN PERSEPSI PENGGUNA KEMENKEU CORPU
}

\author{
Jamila Lestyowati \\ Balai Diklat Keuangan Yogyakarta, Email: jlestyowati@kemenkeu.go.id
}

\section{INFO ARTIKEL}

SEJARAH ARTIKEL

Diterima Pertama

30 Januari 2019

Dinyatakan Dapat Dimuat 31 Desember 2019

\section{KATA KUNCI:}

Brand Image,

Corporate University,

Brand identity,

Brand personality,

Brand association

Brand attitude and behavior.

\begin{abstract}
ABSTRAK
This study aims to analysis the effect of brand image dimensions on brand image and perceptions of MOF Corpu's users. The research methods were quantitative and qualitative. Quantitative method used multiple regression analysis to examine the effect of brand image's dimension on brand image, while qualitative to examine the effect of brand image on perceptions Corpu of users. The sample used was 109 respondents. The results showed that overall factors had significant effect on brand image. Individually, brand association had significant effect on brand image. The other dimensions, namely brand identity, brand personality and brand attitude and behavior had no significant effect on brand image. Brand image itself had a positive effect on consumer perceptions, during training because it improves their performance in the workplace. Research on brand image has not be done in $M O F$, and it supports BPPK's efforts to improve its performance as the first Corpu in the Indonesian government.
\end{abstract}

Penelitian ini untuk menganalisis pengaruh dimensi brand image terhadap brand image dan persepsi pengguna Kementerian Keuangan Corporate University. Metode penelitian adalah gabungan kuantitatif dan kualitatif. Metode kuantitatif menggunakan analisis regresi berganda untuk melihat pengaruh dimensi brand image terhadap brand image, sedangkan metode kualittatif untuk melihat pengaruh brand image terhadap persepsi tentang Corporate University pada pengguna. Sampel yang digunakan sebanyak 109 responden. Hasil pengujian menunjukkan secara keseluruhan terdapat pengaruh signifikan antara dimensi brand image dengan brand image. Secara individual brand attitude and behavior dan brand association berpengaruh signifikan terhadap brand image. Dimensi lainnya yaitu brand identity dan brand personality tidak berpengaruh signifikan terhadap brand image. Brand image sendiri berpengaruh positif terhadap persepsi konsumen yaitu saat pelatihan karena meningkatkan performa mereka di tempat kerja. Penelitian mengenai brand image baru dilakukan di lingkup Kemenkeu, dan ini mendukung upaya BPPK untuk meningkatkan performa dirinya sebagai Corpu pertama di pemerintah Indonesia.

\section{PENDAHULUAN}

\subsection{Latar Belakang}

Organisasi pada dasarnya digunakan sebagai tempat atau wadah bagi orang-orang untuk berkumpul, bekerjasama secara rasional dan sistematis, terencana, terpimpin dan terkendali, dalam memanfaatkan sumber daya (uang, material, mesin, metode, lingkungan), sarana-prasarana, data, dan lain sebagainya yang digunakan secara efisien dan efektif untuk mencapai tujuan organisasi. Dalam perkembangannya, organisasi bisa berkembang, bertahan, stagnan, menyusut bahkan hilang.

Banyak teori modern yang mendefinisikan keberadaan organisasi dan pentingnya bagi organisasi untuk berubah agar mampu bertahan dan berkembang. Rhenald Kasali memberi masukan bahwa agar pemerintahan dapat bekerja efektif yaitu melalui adaptasi dan manajemen. Entitas tidak dituntut untuk berubah, melainkan beradaptasi. Bangsa-bangsa gagal merespon krisis bukanlah bangsa yang tidak mau berubah, melainkan gagal beradaptasi (Kasali, 2014). Metode perubahan Kotter dipakai untuk membantu organisasi mencapai kesuksesan dalam mengimplementasikan adanya suatu perubahan. Kuncinya adalah organisasi tersebut mampu berubah dan menyesuaikan diri. Organisasi memang harus dipaksa untuk berubah. Jika tidak segera berubah maka organisasi akan tertinggal jauh oleh pesaing-pesaingnya. 
Badan Pendidikan dan Pelatihan Keuangan (BPPK) merupakan salah satu institusi di bawah Kementerian Keuangan. Berdasarkan Peraturan Presiden Nomor 28 tahun 2015 tentang Kementerian Keuangan, BPPK mempunyai tugas menyelenggarakan pendidikan, pelatihan, dan sertifikasi kompetensi di bidang keuangan negara sesuai dengan ketentuan peraturan perundangundangan. Dalam melaksanakan tugas tersebut, BPPK menyelenggarakan fungsi sebagai berikut.

a. Penyusunan-penyusunan kebijakan teknis, rencana dan program pendidikan, pelatihan dan sertifikasi kompetensi di bidang keuangan negara.

b. Pelaksanaan pendidikan, pelatihan, dan sertifikasi kompetensi di bidang keuangan negara.

c. Pemantauan, evaluasi, dan pelaporan pelaksanaan pendidikan, pelatihan dan sertifikasi kompetensi dan pemanfaatan hasil pendidikan di bidang keuangan negara.

d. Pelaksanaan administrasi Badan Pendidikan dan Pelatihan Keuangan.

e. Pelaksanaan fungsi lain yang diberikan oleh Menteri.

Sebagai unit yang bertanggung jawab atas pengembangan SDM Kementerian Keuangan, BPPK menyelenggarakan pendidikan dan pelatihan. Pada Rencana Strategis BPPK tahun 2015 - 2019, BPPK memiliki visi menjadi lembaga pendidikan dan pelatihan terkemuka yang menghasilkan pengelola keuangan negara berkelas dunia. Untuk mencapai visi itu, maka diterapkan konsep Corporate University. Kementerian Keuangan Corporate University akan menjadi organisasi pembelajar (learning organization) melalui pengelolaan dan kapitalisasi pengetahuan seluruh SDM Kementerian Keuangan sehingga memberikan kontribusi sebesar-besarnya bagi pencapaian target kinerja Kementerian Keuangan. Latar belakang Kemenkeu Corpu adalah. knowledge yang ada di Kementerian Keuangan sangat banyak dan beragam, namun masih scattered, melekat pada orang, dan belum terdokumentasikan dengan baik. Selain itu perkembangan teknologi memiliki konsekuensi pada pergeseran metode pembelajaran. Materi belajar harus mudah diakses kapan saja dan dimana saja serta pengembangan SDM harus lebih fokus terhadap pencapaian target kinerja organisasi. Sehingga tujuan Corpu adalah tercapainya SDM Kementerian Keuangan yang mampu memenuhi kinerja organisasi dengan dukungan learning yang applicative, relevant, accesible, and impactfull.

Sebagai sebuah organisasi, produk utama BPPK adalah jasa di bidang pendidikan dan pelatihan keuangan. Para pemakai jasa BPPK adalah pegawai di lingkungan Kementerian Keuangan dan Kementerian/ Lembaga lain, Pemda dan mahasiswa. BPPK memiliki dua jenis konsumen yaitu konsumen individu dan konsumen organisasi. Konsumen individu sering disebut sebagai konsumen akhir. Jenis kedua adalah konsumen organisasi yang meliputi Kemenkeu, K/L lain, Pemda maupun lembaga lainnya (sekolah, pergurusan tinggi dan sebagainya). Kedua jenis konsumen akan mempengaruhi kemajuan maupun kemunduran BPPK. Produk sebaik apapun tidak akan ada artinya bagi BPPK jika ia tidak "dibeli" oleh konsumen. Hubungan yang dekat antara BPPK dengan konsumennya salah satunya ditunjukkan dengan citra merek (brand image) Kemenkeu Corpu yang dikenal baik oleh konsumen.

Merek merupakan nama, istilah, tanda, simbol disain ataupun kombinasinya yang mengidentifikasikan suatu produk/ jasa yang dihasilkan oleh perusahaan. Identifikasi ini juga berfungsi untuk membedakan dnegan produk yang ditawarkan oleh perusahaan pesaing, merek merupakan nilai yang terwakili dalam sebuah trademark (merek dagang) yang mampu menciptakan nilai dan pengaruh tersendiri di pasar bila diatur dengan tepat. Achmad Yanu (2015) menyebut bahwa brand image memiliki pengaruh positif dan signifikan terhadap perilaku pembelian. Sedangkan Asaad (2015) menyatakan bahwa kesadaran merek merupakan solusi untuk mempromosikan produk karena terkait dengan perilaku konsumen.

Merek memegang peranan yang sangat penting untuk menjembatani harapan konsumen pada saat kita menjanjikan sesuatu kepada konsumen. Merek menjadi aset prestisius bagi perusahaan. Membangun persepsi dapat dilakukan melalui jalur merek. Dalam kajian ini peneliti ingin menelisik lebih jauh tentang merek 'Kemenkeu Corpu' sebagai sebuah engine strategis organisasi. Menurut Kotler (2008), dalam pembahasan mengenai merek, banyak hal yang harus dipertimbangkan agar bagaimana produk tersebut dapat diterima oleh konsumen. Caranya adalah menentukan bagaimana konsumen merasa puas dengan adanya merek yang berkualitas. Bagi kebanyakan perusahaan, banyak cara yang digunakan untuk membedakan produk yang dihasilkannya dengan produk perusahaann lain agar konsumen tidak merasa bingung pada saat membeli adalah dengan menggunakan merek pada produknya. Selain sebagai tanda pengenal, merek juga mempunyai fungsi lain seperti simbol prusahaan agar citranya yang baik, pertahanan terhadap persaingan memperoleh kesetiaan konsumen dengan merek yang bagus dan berkualitas, konsumen tidak merasa bingung untuk membeli barang yang sama. Merek yang berkualitas bagus dapat menumbuhkan minat beli konsumen terhadap suatu produk (Kotler, 2008). Merek akan membangun citra merek (brand image). Kotler (2008) menyatakan bahwa brand image (citra merek) adalah seperangkat keyakinan, ide, dan kesan yang dimiliki oleh seseorang terhadap suatu merek. Citra merek ini terdiri dari beberapa dimensi yaitu brand identity, brand personality, brand association, brand attitude and behavior,and brand benefit and Competence. 
Sejak diluncurkan tahun 2016, konsep Kemenkeu Corpu belum dikenal oleh semua peserta pelatihan. Berdasarkan pengamatan awal, masih ada peserta pelatihan di BPPK yang belum tahu konsep Corpu ini. Bahkan ada yang berkomentar bahwa BPPK berubah menjadi Corpu. Penelitian ini akan melihat faktor citra merek Kemenkeu Corpu dalam persepsi Corpu oleh penggunanya. Sejak tahun 2016 saat konsep Corpu diluncurkan melalui program transformasi kelembagaan, BPPK mendapatkan tantangan baru dalam pelaksanaan pelatihan. Faktor kepercayaan dari stakeholder menjadi pemicu untuk pelaksanaan program berikutnya.

Penelitian sebelumnya dilakukan pada sektor privat antara lain Manda Lindeberg, et all (2012), Tamimi, Hoda. et all (2016), Shirazil, Ali. et all., (2013). Yanu (2014), Indra (2016) dan Hung Hung, Chia (2008) yang menghubungkan citra merek, identitas merek, loyalitas merek, nilai yang dirasakan, kepercayaan, dan kepuasan, kepribadian merek, kesetiaan terhadap merek, keputusan pembelian dan loyalitas pelanggan. Pada sektor publik, belum ditemukan ada penelitian yang terkait dengan citra merek dan dimensinya. Peneliti ingin menganalisis pengaruh dimensi-dimensi citra merek (dalam hal ini pada institusi pemerintahan terutama Kemenkeu Corpu dan logo barunya) terhadap citra merek dan persepsi penggunanya. Penelitian ini berguna bagi Kemenkeu Corpu khususnya dan instansi pemerintah pada umumnya terkait dengan konsep public relation sehingga dapat membangun hubungan yang baik dengan stakeholdernya. Oleh karena itu peneliti mengambil judul penelitian ini " Analisis Pengaruh Dimensi Brand Image terhadap Brand Image dan Persepsi Pengguna Kemenkeu Corpu."

\subsection{Rumusan Masalah}

Berdasarkan latar belakang diatas, peneliti membuat rumusan masalah sebagai berikut:

a. Apakah ada pengaruh brand identity terhadap brand image Kemenkeu Corpu?

b. Apakah ada pengaruh brand personality terhadap brand image Kemenkeu Corpu?

c. Apakah ada pengaruh brand association terhadap brand image Kemenkeu Corpu?

d. Apakah ada pengaruh brand attitude and behavior terhadap brand image Kemenkeu Corpu?

e. Apakah ada pengaruh brand image Kemenkeu Corpu terhadap persepsi konsumen?

\subsection{Tujuan}

Penelitian ini dibuat dengan tujuan sebagai berikut:

a. Untuk mengetahui pengaruh brand identity terhadap brand image Kemenkeu Corpu

b. Untuk mengetahui pengaruh brand personality terhadap brand image Kemenkeu Corpu

c. Untuk mengetahui pengaruh brand association terhadap brand image Kemenkeu Corpu d. Untuk mengetahui pengaruh brand attitude and behavior terhadap brand image Kemenkeu Corpu

e. Untuk mengetahui pengaruh brand image Kemenkeu Corpu terhadap persepsi konsumen

\subsection{Manfaat}

Adapun manfaat yang diharapkan dari penelitian ini adalah :

1. Mendapatkan gambaran mengenai pengaruh dimensi citra merk terhadap citra merek dan persepsi kepercayaan pengguna BPPK;

2. Mendapatkan masukan atas pelaksanaan Kemenkeu Corpu;

3. Menjadi dasar bagi penelitian lebih lanjut atas hal-hal yang belum dapat dilakukan dalam penelitian ini.

\section{KERANGKA TEORITIS DAN PENGEMBANGAN HIPOTESIS}

\subsection{Kerangka Teoritis}

\subsubsection{Merek}

Asosiasi Pemasaran Amerika mendefinisikan merek (brand) sebagai "nama, istilah, tanda, simbol, atau rancangan, atau kombinasi dari semuanya, yang dimaksudkan untuk mengidentifikasi barang atau jasa penjual atau kelompok penjual dan untuk mendiferensiasikannya dari barang atau jasa pesaing. Dengan demikian, sebuah merek adalah produk atau jasa penambah dimensi yang dengan cara tertentu mendiferensiasikannya dari produk atau jasa lain yang dirancang untuk memuaskan kebutuhan yang sama.

Ekuitas merek adalah nilai tambah yang diberikan pada produk dan jasa. Nilai ini bisa dicerminkan dalam cara konsumen berfikir, merasa dan bertindak terhadap merek, harga, pangsa pasar dan profitabilitas yang dimiliki perusahaan. Ekuitas merek merupakan aset tak berwujud yang penting, yang memiliki nilai psikologis dan keuangan bagi perusahaan. Mantan profesor UC-Berkeley David Aaker memandang ekuitas merek sebagai satu perangkat dari lima kategori aset dan liabilitas merek yang berkaitan dengan merek yang menambah atau mengurangi nilai yang diberikan sebuah produk atau layana kepada perusahaan/ pelanggan.Menurut Aaker konsep terpenting untuk membangun ekuias merek adalah identitas merek yang terorganisasikan disekitar empat perspektif : merek-sebagai produk (lingkup produk, atribut produk, mutu/ nilai, manfaat, pengguna, negara asal); merek-sebagai organisasi (atribut organisasi, lokal versus global); mereksebagai pribadi (kepribadian merek, hubungan merek-pelanggan); dan merek-sebagai simbol (citra/metaphor visual dan warisan merek). Model resonansi merek memandang penyusunan merek sebagai rangkaian urutan langkah yang meningkat, mulai dari bawah ke puncak: 
1. Memastikan identifikasi merek dengan pelanggan dan asosiasi merek dalam pikiran pelanggan dengan satu kelas produk atau kebutuhan pelanggan spesifik

2. Membangun kokoh arti totalitas merek ke dalam pikiran pelanggan dengan strategi mengaitkan banyak asosiasi merek berwujud dan tak berwujud

3. Memilih tanggapan pelanggan yang memadai dari segi penilaian dan perasaan yang berkaitan dengan merek

4. Membalikkan tanggapan merek untuk menciptakan hubungan loyalitas merek yang intens antara pelanggan dan merek.

Maka merek menjadi pembeda antara suatu produk/ jasa tertentu dengan produk/jasa lainnya.

\subsubsection{Citra Merek (brand Image)}

Brand image memegang peranan penting dalam pengembangan sebuah merek karena citra merek menyangkut reputasi dan kredibilitas merek yang kemudian menjadi "pedoman" bagi khalayak konsumen untuk mencoba atau menggunakan suatu produk barang atau jasa sehingga menimbulkan pengalaman tertentu (brand experience) yang akan menentukan apakah konsumen tersebut akan menjadi loyalis merek atau sekadar oportunis (mudah pindah ke lain merek). Citra merek merupakan representasi dari keseluruhan persepsi terhadap merek dan dibentuk dari informasi dan pengetahuan terhadap merek itu. Citra terhadap merek berhubungan dengan sikap yang berupa keyakinan dan preferensi terhadap suatu merek. Konsumen yang memiliki citra yang positif terhadap suatu merek akan lebih memungkinkan untuk melakukan pembelian (Setiadi, 2003). Citra merek adalah sekumpulan asosiasi merek yang terbentuk pada benak konsumen (Mowen, 1994). Citra merek mengacu pada skema memori akan sebuah merek, yang berisikan interpretasi konsumen atas atribut, kelebihan, penggunaan, situasi, para pengguna, dan karakteristik pemasar dan/ atau karakteristik pembuat dari produk/ merek tersebut. Citra merek adalah apa yang konsumen pikirkan dan rasakan ketika mendengar atau melihat nama suatu merek. Atau dengan kata lain, citra merek merupakan bentuk atau gambaran tertentu dari suatu jejak makna yang tertinggal di benak khalayak konsumen (Wijaya, 2011), yang kemudian menuntun khalayak konsumen tersebut untuk bersikap terhadap merek, apakah akan mencoba lalu menyetiainya atau sekadar coba-coba lalu pergi, atau sama sekali tidak ingin mencoba karena citra yang buruk atau tidak relevan dengan kebutuhan khalayak konsumen.

Citra merek merupakan serangkaian asosiasi yang ada dalam benak konsumen terhadap suatu merek, biasanya terorganisasi menjadi suatu makna. Hubungan terhadap suatu merek akan semakin kuat jika didasarkan pada pengalaman dan mendapat banyak informasi. Citra atau asosiasi merepresentasikan persepsi yang bisa merefleksikan kenyataan yang objektif ataupun tidak. Citra yang terbentuk dari asosiasi inilah yang mendasari dari keputusan membeli bahkan loyalitas merek (brand loyalty) dari konsumen. Konsumen lebih sering membeli produk dengan merek yang terkenal karena merasa lebih nyaman dengan hal-hal yang sudah dikenal, adanya asumsi bahwa merek terkenal lebih dapat diandalkan, selalu tersedia dan mudah dicari, dan memiliki kualitas yang tidak diragukan, sehingga merek yang lebih dikenal lebih sering dipilih konsumen daripada merek yang tidak (Aaker, 1991).

Citra merek meliputi pengetahuan dan kepercayaan akan atribut merek (aspek kognitif), konsekuensi dari penggunaan merek tersebut, dan situasi penggunaan yang sesuai, begitu juga dengan evaluasi, perasaan dan emosi yang diasosiasikan dengan merek tersebut (aspek Afektif). Citra merek didefinisikan sebagai persepsi konsumen dan preferensi terhadap merek, sebagaimana yang direfleksikan oleh berbagai macam asosiasi merek yang ada dalam ingatan konsumen. Meskipun asosiasi merek dapat terjadi dalam berbagai macam bentuk tapi dapat dibedakan menjadi asosiasi performansi dan asosiasi imajeri yang berhubungan dengan atribut dan kelebihan merek (Peter \& Olson, 2002).

Fungsi dan Peran Citra Merek

Boush dan Jones (dalam Kahle \& Kim, 2006: 6-8) mengemukakan bahwa citra merek (brand image) memiliki beberapa fungsi, di antaranya sebagai pintu masuk pasar (market entry), sumber nilai tambah produk (source of added product value), penyimpan nilai perusahaan (corporate store of value), dan kekuatan dalam penyaluran produk (channel power). Berkaitan dengan fungsi market entry, citra merek berperan penting dalam hal pioneering advantage, brand extension dan brand alliance. Produk pionir dalam sebuah kategori yang memiliki citra merek kuat akan mendapatkan keuntungan karena biasanya produk follower kalah pamor dengan produk pionir, misalnya Aqua. Bagi follower tentunya akan membutuhkan biaya tinggi untuk menggeser produk pionir yang memiliki citra merek kuat tersebut. Di sinilah keuntungan produk pionir (firstmover/pioneering adavantages) yang memilki citra merek kuat dibandingkan produk pionir yang memiliki citra lemah atau produk komoditi tanpa merek.

Citra merek juga memungkinkan perusahaan untuk mengembangkan merek dari satu pasar produk ke pangsa pasar lain melalui perluasan merek (Aaker, 1989; Aaker \& Keller, 1990; Boush \& Loken, 1991; Tauber, 1988). Strategi ekstensi merek (brand extension) telah menjadi semakin menarik sebagai cara untuk mengurangi biaya yang luar biasa dari pengenalan produk baru. Riset Suharyanti (2011) mengungkapkan pengaruh citra merek induk terhadap sub-merek hasil ekstensi terjadi pada transfer atribut dan persepsi kecocokan serta kredibilitas perusahaan yang menaunginya. 
Salah satu strategi yang paling populer untuk meningkatkan citra merek adalah melalui aliansi merek (brand alliance). Sebuah aliansi merek dapat digambarkan sebagai hubungan jangka pendek atau panjang atau kombinasi atribut berwujud (tangibles) dan tidak berwujud (intangibles) yang terkait dengan mitra merek (Rao \& Ruekert, 1994). Salah satu tipe paling populer dari aliansi merek adalah kemitraan co-brand. Co-branding dapat didefinisikan sebagai penempatan dua nama merek pada satu produk atau paket (Lamb, Hair, McDaniel, 1998; Shocker, 1995).

Fungsi berikutnya dari citra merek adalah sebagai sumber nilai tambah produk (source of added product value). Para pemasar mengakui bahwa citra merek tidak hanya merangkum pengalaman konsumen dengan produk dari merek tersebut, tapi benar-benar dapat mengubah pengalaman itu. Sebagai contoh, konsumen terbukti merasa bahwa makanan atau minuman dari merek favorit mereka memiliki rasa yang lebih baik dari kompetitor jika diuji secara unblinded dibandingkan jika diuji secara blinded taste tests (Allison \& Uhl, 1964). Dengan demikian citra merek memiliki peran yang jauh lebih kuat dalam menambah nilai produk dengan mengubah pengalaman produk (Aaker \& Stayman, 1992; Puto \& Wells, 1984).

Fungsi lain dari citra merek adalah sebagai penyimpan nilai perusahaan (corporate store of value). Nama merek merupakan penyimpan nilai dari hasil investasi biaya iklan dan peningkatan kualitas produk yang terakumulasikan. Perusahaan dapat menggunakan penyimpan nilai ini untuk mengkonversi ide pemasaran strategis menjadi keuntungan kompetitif jangka panjang. Misalnya, merek Hallmark diuntungkan dari keputusan yang dibuat selama 1950 untuk mensponsori beberapa program televisi berkualitas tinggi secara khusus setiap tahun.

Sementara itu, nama merek dengan citra yang kuat berfungsi baik sebagai indikator maupun kekuatan dalam saluran distribusi (channel power). Ini berarti merek tidak hanya berperan penting secara horizontal, dalam menghadapi pesaing mereka, tetapi juga secara vertikal, dalam memperoleh saluran distribusi dan memiliki kontrol dan daya tawar terhadap persyaratan yang dibuat distributor (Aaker, 1991; Porter, 1974). Sebagai contoh, strategi merek ekstensi Coca Cola bisa dibilang menyelesaikan tiga fungsi sekaligus. Perpanjangan izin masuk pasar dengan biaya lebih rendah, menghambat persaingan dengan menguasai shelf space, dan juga dapat memberikan daya tawar dalam hal negosiasi perdagangan, karena Coca Cola dianggap memiliki kekuatan dalam meningkatkan penjualan.

Hogan (2005) mengungkapkan bahwa citra merek merupakan asosiasi dari semua informasi yang tersedia mengenai produk, jasa dan perusahaan dari merek yang dimaksud. Informasi ini didapat dari dua cara; yang pertama melalui pengalaman konsumen secara langsung, yang terdiri dari kepuasan fungsional dan kepuasan emosional. Merek tersebut tidak cuma dapat bekerja maksimal dan memberikan penampilan hasil yang dijanjikan tapi juga harus dapat memahami kebutuhan konsumen, mengusung nilai-nilai yang diinginkan. Citra merek memiliki peran penting dalam mempengaruhi perilaku pembelian (Alif Fianto, 2014, cahyani, 2016, Hung, 2008, Karam, 2015).

Oleh karena itu, citra merek berhubungan dengan sesuatu yang dengan cara apa merek itu digambarkan dan dikenang.

\subsubsection{Brand Identity}

Dimensi brand identity merupakan identitas fisik yang berkaitan dengan merek atau produk tersebut sehingga konsumen mudah mengenali dan membedakannya dengan merek atau produk lain, seperti logo, warna, kemasan, lokasi, identitas perusahaan yang memayunginya, slogan, dan lainlain. Shirazi (2013) menunjukkan bahwa identitas merek maupun merek Identifikasi memiliki pengaruh tidak langsung pada loyalitas merek melalui nilai yang dirasakan, kepercayaan, dan kepuasan. Hal ini sejalan dengan hasil penelitian Tamimi (2013). Dalam kasus lain muncul celah komunikasi antara identitas merek dan citra merek pelanggan ketika menyangkut konsep kepribadian, pemosisian, visi dan budaya, dan hubungan (Lindeberg, 2012).

Identitas merek menghubungkan antara identitias fisik merek produk tertentu dengan gambaran yang ingin didapatkan dari merek tersebut.

\subsubsection{Brand Personality}

Dimensi brand personality (personalitas merek) adalah karakter khas sebuah merek yang membentuk kepribadian tertentu sebagaimana layaknya manusia, sehingga khalayak konsumen dengan mudah membedakannya dengan merek lain dalam kategori yang sama, misalnya karakter tegas, kaku, berwibawa, ningrat, atau murah senyum, hangat, penyayang, berjiwa sosial, atau dinamis, kreatif, independen, dan sebagainya.

Brand Personality merupakan serangkaian karakteristik manusia yang oleh konsumen diasosiasikan dengan merek tersebut, seperti kepribadian, penampilan, nilai-nilai, kesukaan, gender, ukuran, bentuk, etnis, inteligensi, kelas sosioekonomi, dan pendidikan. Hal ini membuat merek seakan-akan hidup dan mempermudah konsumen mendeskripsikannya, serta faktor penentu apakah konsumen ingin diasosiasikan dengan merek tersebut atau tidak. Kepribadian dan karakter merek membantu pemasar lebih mengerti kelebihan dan kekurangan merek tersebut dan cara memosisikan merek secara tepat. Brand personality menjelaskan mengapa orang menyukai merek-merek tertentu dibandingkan merek lain ketika tidak ada perbedaan atribut fisik yang cukup besar antara merek yang satu 
dengan yang lain. David Ogilvy (dalam Sengupta, 2005) menyebutkan bahwa kepribadian merek merupakan kombinasi dari berbagai hal: nama merek, kemasan merek, harga produk, gaya iklan, dan kualitas produk itu sendiri.

Brand personality menjadikan produk seperti seorang person lengkap dengan atribut yang terdapat di dalamnya.

\subsubsection{Brand Association}

Dimensi brand association (asosiasi merek) adalah hal-hal spesifik yang pantas atau selalu dikaitkan dengan suatu merek, bisa muncul dari penawaran unik suatu produk, aktivitas yang berulang dan konsisten misalnya dalam hal sponsorship atau kegiatan social responsibility, isu-isu yang sangat kuat berkaitan dengan merek tersebut, ataupun person, simbol-simbol dan makna tertentu yang sangat kuat melekat pada suatu merek, misalnya "ingat beras ingat cosmos", art+technology=apple, bola=Djarum, koboi=Marlboro, kulit putih=Ponds, Bola=Djarum, Konflik=PSSI, Gramedia=Buku, Lifebuoy=Kebersihan, dan sebagainya.

Brand Associations merupakan asosiasi terhadap karakteristik produk atau jasa yang dilekatkan oleh konsumen pada merek tersebut, termasuk persepsi konsumen mengenai janji-janji yang dibuat oleh merek tersebut, positif maupun negatif, dan harapan mengenai usaha-usaha untuk mempertahankan kepuasan konsumen dari merek tersebut. Suatu merek memiliki akar yang kuat, ketika merek tersebut diasosiasikan dengan nilai-nilai yang mewakili atau yang diinginkan oleh konsumen. Asosiasi merek membantu pemasar mengerti kelebihan dari merek yang tersampaikan pada konsumen.

Brand associations menjadikan sebuah merek memiliki kaitan dengan konsep lain yang ingin disampaikan ke khalayak.

\subsubsection{Brand Attitude and Behavior}

Dimensi brand attitude (sikap dan perilaku merek) adalah sikap atau perilaku komunikasi dan interaksi merek dengan konsumen dalam menawarkan benefit-benefit dan nilai yang dimilikinya. Kerap sebuah merek menggunakan caracara yang kurang pantas dan melanggar etika dalam berkomunikasi, pelayanan yang buruk sehingga memengaruhi pandangan publik terhadap sikap dan perilaku merek tersebut, atau sebaliknya, sikap dan perilaku simpatik, jujur, konsisten antara janji dan realitas, pelayanan yang baik dan kepedulian terhadap lingkungan dan masyarakat luas membentuk persepsi yang baik pula terhadap sikap dan perilaku merek tersebut. Jadi brand attitude \& behavior mencakup sikap dan perilaku komunikasi, aktivitas dan atribut yang melekat pada merek saat berhubungan dengan khalayak konsumen, termasuk perilaku karyawan dan pemilik merek.
Brand Attitude (sikap merek) yang didefinisikan sebagai evaluasi keseluruhan atas suatu merek, apa yang dipercayai oleh konsumen mengenai merekmerek tertentu, sejauh apa konsumen percaya bahwa produk atau jasa tersebut memiliki atribut atau keuntungan tertentu, dan penilaian evaluatif terhadap kepercayaan tersebut -bagaimana baik atau buruknya suatu produk jika memiliki atribut atau keuntungan tersebut. Wijaya (2011b:21) menyebutkan bahwa brand attitude lebih merupakan sikap atau perilaku komunikasi dan interaksi merek dengan konsumen yang memengaruhi citra merek tersebut.

Brand Attitude menghubungkan keyakinan konsumen terhadap merek tertentu.

\subsubsection{Persepsi Konsumen}

Persepsi dapat didefinisikan sebagai cara konsumen melihat dan melekatkan makna pada semua input informasi yang datang dalam kehidupan sehari-hari. Setiap input informasi akan diproses oleh konsumen secara selektif memilih (input yang paling penting/relevan), mengorganisasi, dan menginterpretasi atau memaknai input informasi sehingga memberikan gambaran objek yang memiliki kebenaran subjetif (bersifat personal), memiliki arti tertentu, dapat dirasakan. Input informasi ini dapat dalam bentuk kata-kata (baru), musik/lagu (baru) atau iklan suatu produk.

Kotler menyatakan, "persepsi adalah proses yang digunakan oleh individu untuk memilih, mengorganisasi, dan menginterpretasi masukan informasi guna menciptakan gambaran yang memiliki arti”. Sedangkan menurut Schiffman \& Kanuk (2008) "persepsi didefinisikan sebagai proses yang dilakukan individu untuk memilih, mengatur, dan menafsirkan stimuli ke dalam gambar yang berarti dan masuk akal mengenai dunia". Persepsi tidak hanya tergantung pada rangsangan dalam bentuk fisik, tetapi juga tergantung pada rangsangan yang ada disekitarnya dan kondisi yang ada pada seseorang dan persepsi lebih penting dibandingkan realitas dalam pemasaran, karena persepsi yang dapat mempengaruhi konsumen dalam berperilaku, selain itu orang bisa mempunyai persepsi yang berbeda atas objek yang sama.

Persepsi konsumen akan memengaruhi konsumen pada pilihan menggunakan atau tidak tehadap suatu produk.

\subsubsection{Corporate University}

Sepanjang lima belas tahun belakangan, praktisi dan akademisi telah merumuskan berbagai defiisi untuk memahami konsep Corporate University. Beberapa definisi mengarah ke strategi generic, namun kebanyakan menggambarkan Corporate University sebagai suatu entitas organisasi.

Di dunia korporasi, Corporate University diterima secara luas namun tanpa definisi yang jelas. Pengetahuan tentang Corporate University 
terfragmentasi secara alami. Memang, diatas semua itu Corporate University masih dalam proses pembentukan. Penciptaan definisi tersebut akan berguna untuk menyediakan titik acuan umum konsep pengembangan di masa depan. Sehingga diusulkan definisi Corporate University adalah sebuah unit, pendekatan atau konsep yang mendukung pembaruan, implementasi dan/atau optimasi strategi melalui pembelajaran organisasi (Martyn, 2017). Sedangkan pembelajaran organisasi adalah pengembangan wawasan, pengetahuan dan hubungan antara tindakan masa lalu, efektivitas dari tindakantindakan tersebut, dan tindakan masa depan yang akan berdampak pada kelangsungan hidup jangka panjang suatu organisasi.

Banyak organisasi mengembangkan dan memanfaatkan Corporate University mereka. Salah satunya adalah Kementerian Keuangan. Berdasarkan Keputusan Kepala BPPK Nomor KEP- 140/PP/2017 tentang Cetak Biru Kementerian Keuangan Corporate University, BPPK sebagai unit yang bertanggung jawab atas pengembangan SDM Kementerian Keuangan melalui pendidikan dan pelatihan. Pada Rencana Strategis BPPK tahun 2015 - 2019, BPPK memiliki visi menjadi lembaga pendidikan dan pelatihan terkemuka yang menghasilkan pengelola keuangan negara berkelas dunia. Untuk mencapai tujuan itu, maka diterapkan konsep Corporate University. Kementerian Keuangan Corporate University (Kemenkeu Corpu) merupakan strategi yang digunakan untuk mencapai visi dan misi Kementerian Keuangan, dengan mewujudkan link and match antara pembelajaran, pengelolaan pengetahuan, dan penerapan nilai-nilai dengan target kinerja Kementerian Keuangan dan dilaksanakan oleh seluruh elemen Kementerian Keuangan dengan BPPK sebagai motor penggerak utama bagi SDM keuangan negara. Corporate University bertanggung jawab dalam pengembangan SDM serta peningkatan kapabilitas dan daya saing organisasi, sehingga Corporate University harus mampu go beyond training and development dalam memastikan bahwa ilmu yang didapatkan dapat diimplementasikan dan memiliki link and match dengan target kinerja Kementerian Keuangan.

Untuk lebih mengenalkan Corporate University kepada semua stakeholder baik internal maupun eksternal, maka ditetapkan logo Kementerian Keuangan Corporate University. Identitas merupakan hal yang penting dalam membentuk citra sebuah organisasi. Dalam rangka melakukan rebranding Kementerian Keuangan Corporate University, telah disusun logo yang ditetapkan dalam Keputusan Menteri Keuangan 563/KMK.011/2017 tentang Logo Kementerian Keuangan Corporate University sebagai berikut:

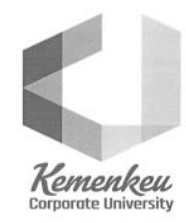

Gambar 1. Logo Kemenkeu Corpu

Adapun arti logo tersebut adalah :

* Huruf C melambangkan Corporate.

* Huruf U melambangkan University.

* Bentuk dasar heksagonal seperti sarang lebah melambangkan semangat efisiensi dan sinergi dalam bekerja.

* Warna biru melambangkan profesionalisme, kredibilitas, dan integritas.

* Warna kuning melambangkan optimisme dan semangat.

* Mode multiply (perpaduan warna yang bertumpuk sehingga menghasilkan warna yang lebih gelap) mempunyai maksud sinergitas dalam unit-unit di Kementerian Keuangan.

Kemenkeu Corpu adalah strategi yang diambil dan BPPK sebagai penggerak utamanya. Sehingga BPPK sebagai organisasi tetap ada dan bahkan mendapat peran lebih sebagai lembaga pendidikan dan pelatihan. Dalam konteks manajemen sumber daya manusia, pelatihan dan pengembangan mempunyai kegunaan pada karir jangka panjang SDM untuk membantu menghadapi tanggung jawab yang lebih besar di masa yang akan datang. Program ini tidak hanya bermanfaat pada individu tetapi juga pada organisasi.

\subsection{Kerangka Pemikiran}

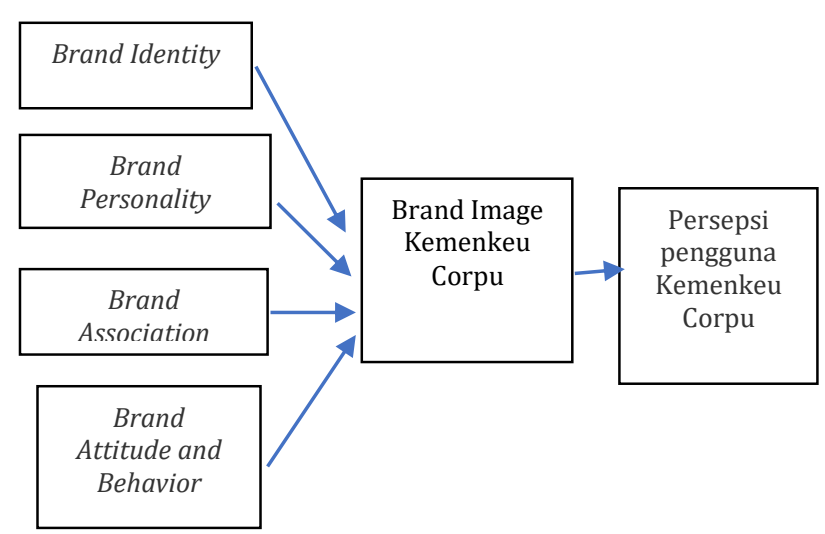

Gambar 2. Kerangka Pemikiran Pengaruh Dimensi Brand Image Terhadap brand Image dan Persepi Pengguna Kemenkeu Corpu

\subsection{Hipotesis}

Hipotesis menyatakan hubungan yang diduga secara logis antara dua variabel atau lebih dalam rumusan proposisi yang dapat diuji secara empiris. Hipotesis dikembangkan dari telaah teoritis atau literatur. Berdasarkan tinjauan pustaka diatas, maka peneliti membuat hipotesis sebagai berikut: 
a. Brand identity berpengaruh positif terhadap brand image Kemenkeu Corpu

b. Brand personality berpengaruh positif terhadap brand image Kemenkeu Corpu

c. Brand association berpengaruh positif terhadap brand image Kemenkeu Corpu

d. Brand attitude and behavior berpengaruh positif terhadap brand image Kemenkeu Corpu

e. Brand image Kemenkeu Corpu berpengaruh positif terhadap persepsi konsumen terhadap Kemenkeu Corpu

\section{METODOLOGI PENELITIAN}

\subsection{Ruang Lingkup dan Jenis Penelitian}

Penelitian ini bertujuan menganalisis pengaruh Brand Identity, Brand Personality, Brand Association, dan Brand Attitude and Behavior terhadap Citra merek. Jenis penelitian yang akan dilakukan sesuai dengan tujuan yang telah ditetapkan yaitu untuk mengenai hubungan antara dimensi citra merek Kemenkeu Corpu terhadap citra merek dan persepsi terhadap Kemenkeu Corpu. Penelitian ini merupakan jenis penelitian gabungan antara kuantitatif dan kualitatatif. Penelitian kuantitatif pada analisis pengaruh dimensi citra merek terhadap merek, sedangkan penelitian kualitatif dilakukan untuk menganalisis hubungan citra merek terhadap persepsi pengguna Kemenkeu Corpu.

\subsection{Jenis dan Sumber Data}

Penelitian ini menggunakan data yang berasal dari data primer yaitu data yang didapatkan langsung dari sumber data (Creswell, 2018). Data diperoleh dari hasil kuesioner yang diisi oleh para responden yaitu peserta pelatihan baik yang berasal dari BPPK sendiri maupun diluar BPPK selama kurun waktu April - Mei 2018. Selain itu juga dilakukan penelitian kepustakaan dan in depth interview untuk menunjang penelitian ini.

\subsection{Definisi Operasional Variabel}

Dalam penelitian ini, diberikan definisi operasional variabel sebagai berikut:

1. Citra merek adalah representasi dari keseluruhan persepsi terhadap merek Kemenkeu Corpu yang dibentuk dari informasi dan pengetahuan terhadap merek itu, keyakinan dan preferensi terhadap merek dan apa yang peserta pelatihan pikirkan dan rasakan ketika mendengar atau melihat nama merek Kemenkeu Corpu.

2. Brand Identity adalah identitas fisik yang berkaitan dengan merek Kemenkeu Corpu sehingga konsumen mudah mengenali dan membedakannya dengan lain, seperti logo, warna, identitas BPPK, dan slogan

3. Brand Personality adalah karakter khas Kemenkeu Corpu yang membentuk kepribadian tertentu sebagaimana layaknya manusia, misalnya karakter applicative, relevant, accesible, and impactfull.

4. Brand Association adalah hal-hal spesifik yang pantas atau selalu dikaitkan dengan suatu merek Kemenkeu Corpu, yang muncul dari keunikan suatu produk, aktivitas yang berulang dan konsisten. Ingat pelatihan ingat BPPK.

5. Brand Attitude and Behavior adalah sikap atau perilaku komunikasi dan interaksi merek Kemenkeu Corpu dengan stakeholder dalam menawarkan benefit-benefit pelatihan dan nilai yang dimilikinya.

6. Persepsi Kemenkeu Corpu adalah proses memilih, mengatur dan menginterpretasikan informasi mengenai layanan kepelatihanan oleh stakeholder pelatihan yaitu BDK Yogyakarta paska diterapkannya konsep Corpu

\subsection{Instrumen Penelitian}

Terdapat lima variabel kuantitatif yang diteliti, yaitu Brand Image, Brand Identity, Brand Personality, Brand Assosiation, Brand Attitude and Behavior. Variabel persepsi pengguna Kemenkeu Corpu menjadi variabel kualitatif. Instrumen penelitian menggunakan kuesioner skala likert dengan lima pilihan jawaban, yaitu Sangat tidak setuju (STS), Tidak setuju (TS), Netral (N), Setuju (S) dan Sangat Setuju (SS). Selain itu, peneliti juga menggunakan wawancara terstruktur kepada responden untuk mengetahui persepsi pengguna terhadap Kemenkeu Corpu.

\subsection{Metode Analisis Data}

Penelitian menggunakan analisis deskriptif kuantatif dan kualitatif. Analisis kuantitatif dengan model ekonometrik metode Regresi Linier Berganda (OLS) menggunakan software SPSS untuk memudahkan perhitungan maupun estimasi data.

\subsection{Model Penelitian dan Pengujian Data}

Model kuantitatif yang digunakan dalam penelitian ini sebagai berikut:

Brand Image $=\alpha_{1}+\beta_{1}$ Brand Identity + $\beta_{2}$ Brand Personality $+\beta_{3}$ Brans Assosiacion + $\beta_{4}$ Brand Attitude and Behavior $+\varepsilon \ldots$

Keterangan:
$\alpha, \beta$
: Parameter
$\varepsilon$
: Error

Model tersebut kemudian diuji menggunakan koefisien determinasi $\left(\mathrm{R}^{2}\right)$, pengujian t-statistik dan uji F-Statistik. Agar mendapatkan hasil yang akurat pada analisis regresi, maka dilakukan pengujian pada masalah regresi yaitu uji normalitas, uji linearitas, multikolinearitas dan heteroskedastisitas sehingga mendapatkan hasil yang fit. 


\section{HASIL PENELITIAN DAN PEMBAHASAN}

\subsection{Hasil Penelitian}

Penelitian ini dilakukan untuk mengetahui pengaruh dimensi Brand Image terhadap Brand Image dan Persepsi Pengguna Kementerian Keuangan Corporate University. Adapun dimensi brand image terdiri dari brand identity, brand personality, brand association, dan brand attitude and behavior. Peneliti menetapkan BPPK sebagai obyek penelitian karena memandang konsep Corpu sebagai sesuatu yang baru, untuk kemudian dihubungan dengan konsep pemasaran. Dalam penelitian ini, sampel yang dipakai adalah peserta pelatihan di BDK Yogyakarta. Pelatihan yang digunakan sebagai unit analisis adalah pelatihan Latsar Golongan II Periode III tahun 2017 kelas F berjumlah 29 orang dengan peserta generasi milenial yang peneliti anggap mewakili pegawai baru Kementerian Keuangan unit organisasi DJP dan DJBC penempatan seluruh Indonesia, Pelatihan Treasury Management Representative dengan peserta dari DJPb seluruh Indonesia berjumlah 25 orang, Pelatihan Tenaga Pendamping Penyusunan Laporan Keuangan dengan peserta dari DJPB sebanyak 31 orang dan Pelatihan Manajemen Pembelajaran dengan peserta dari BPPK unit organisasi BDK seluruh Indonesia berjumlah 24 orang.

Karakteristik responden

Berdasarkan data kuesioner yang masuk, didapatkan data karakteristik responden sebagai berikut.

Tabel 4.1. Karakteristik Responden

\begin{tabular}{|c|c|c|}
\hline \multirow{4}{*}{ Usia } & $20-30$ tahun & 49 \\
\cline { 2 - 3 } & $31-40$ tahun & 23 \\
\cline { 2 - 3 } & $41-50$ tahun & 18 \\
\cline { 2 - 3 } Jenis Kelamin & $51-60$ tahun & 19 \\
\hline \multirow{3}{*}{ Pendidikan } & Laki-laki & 72 \\
\cline { 2 - 3 } & Perempuan & 37 \\
\cline { 2 - 3 } & Diploma & 53 \\
\cline { 2 - 3 } & S1 & 37 \\
\cline { 2 - 3 } & S2/S3 & 3 \\
\hline Jabatan & SLTA & 16 \\
\hline & Eselon IV & 10 \\
\hline & Pelaksana & 99 \\
\hline & & \\
\hline
\end{tabular}

Sumber : data primer

Sebagian besar responden (49\%) berusia muda yaitu antara 20 - 30 tahun. Peserta ini adalah pegawai baru di Kementerian Keuangan, yaitu peserta pelatihan Latsar Golongan II dan pelatihan Manajemen Pembelajaran. Berdasarkan jenis kelamin, sebagian besar responden berjenis kelamin laki-laki, yaitu 72\%. Diantara responden, sebagian besar (53\%) tingkat pendidikannya adalah Diploma. Mereka berasal dari alumni PKN STAN baik Diploma Satu maupun Diploma Tiga. Pada kelomok pendidikan yang lain, diantara mereka juga ada yang kuliah di STAN, yang kemudian melanjutkan pendidikan ke tingkat yang lebih tinggi. Sebanyak 53\% responden merupakan lulusan diploma, dan 37\% dari S1. Sisanya adalah SLTA dan S2/S3. Sebanyak 99\% responden adalah pelaksana di kantor. Karena banyak yang masih pegawai baru, maka mereka masih menduduki jabatan pelaksana. Sedangkan $1 \%$ sudah menduduki jabatan eselon IV.

Tabel 4.2. Karakteristik Responden Pernah pelatihan 2017 sd sekarang \begin{tabular}{l|l} 
Valid & Cuml.
\end{tabular}

\begin{tabular}{llll|l|l} 
& & Freq. & Percent & Percent & $\begin{array}{l}\text { Puml. } \\
\text { Percent }\end{array}$ \\
\hline Valid & Pernah & 109 & 100.0 & 100.0 & 100.0 \\
\hline
\end{tabular}

Sumber : data primer

Semua responden pernah mengikuti pelatihan yang diselenggarakan olah BPPK selama rentang waktu 2017 sampai dengan sekarang. Paling tidak pada saat mengisi kuesioner, responden sedang berada pada posisi sebagai peserta pelatihan. Oleh karena itu, responden sedang mengikuti pelatihan model corporate university.

Tabel 4.3. Karakteristik Responden Pernah pelatihan sebelum 2017 Perce Valid Cuml.

\begin{tabular}{lll|l|l|l} 
& & Freg. & $\begin{array}{l}\text { Perce } \\
\text { nt }\end{array}$ & $\begin{array}{l}\text { Valid } \\
\text { Percent }\end{array}$ & $\begin{array}{l}\text { Cuml. } \\
\text { Percent }\end{array}$ \\
\hline \multirow{3}{*}{ Valid } & Belum Pernah & 39 & 35.8 & 35.8 & 35.8 \\
\cline { 2 - 6 } & Pernah & 70 & 64.2 & 64.2 & 100.0 \\
\cline { 2 - 6 } & Total & 109 & 100.0 & 100.0 & \\
\hline
\end{tabular}

Sumber : data primer

Diantara responden, 70\% pernah mengikuti pelatihan yang diselenggarakan BPPK sebelum tahun 2017. Dengan demikian, responden dapat membedakan pelatihan yang diselenggaran sebelum dan sesudah BPPK menerapkan strategi corporate university.

\subsection{Analisis Data}

Dalam penelitian ini analisis data yang digunakan ada tiga macam, yaitu uji instumen, uji prasyarat, dan uji hipotesis.

a. Uji instrumen validitas menggunakan nilai Pearson Correlation yang menunjukkan butir pertanyaan valid atau tidak. Butir Q1, Q5, dan Q38 tidak valid dan dikeluarkan dari instrumen penelitian. Uji reliabilitas instrumen menggunakan nilai Alpha Cronbach's mendapatkan hasil bahwa 51 butir pertanyaan dalam kuesioner pengukuran dimensi brand image dan brand image sudah valid dan reliabel sehingga dapat dipakai sebagai instrument penelitian.

b. Uji Pra-syarat Analisis (Asumsi Klasik)

1) Uji Normalitas melalui serangkaian tindakan menunjukkan semua data berdistribusi normal.

2) Uji Linieritas

Hasil uji menunjukkan ada hubungan yang linier antara dimensi brand image terhadap brand imag maka model regresi dapat digunakan untuk memprediksi tingkat pengaruh brand image.

3. Uji Multikolinearitas

Hasil Output SPSS menunjukkan nilai $r$ nya kurang dari 0,8 , maka gejala multikolinearitas tidak terdeteksi.

4. Uji heteroskedastisitas 
Persamaan regresi yang baik jika tidak terjadi heteroskedastisitas. Dari tabel scatterplot, didapat hasil titik menyebar di bawah serta di atas sumbu Y, dan tidak mempunyai pola yang teratur. Maka dapat disimpulakan variabel bebas di atas tidak terjadi heteroskedastisitas atau bersifat homoskedastisitas.

c. Pengujian Hipotesis

Pengujian hipotesis meliputi Uji F-Statistik, Uji tStatistik dan Koefesien Determinasi $\left(\mathrm{R}^{2}\right)$. Selengkapnya pengujian hipotesis diuraikan sebagai berikut.

\section{Uji F-Statistik}

Tabel 4.4. Output Uji Hipotesis SPSS 25 Model Summaryb

\begin{tabular}{|c|c|c|c|c|c|c|c|c|}
\hline & & & del s & mary & & & & \\
\hline & & & & Change & Stati & tics & & \\
\hline & & & Std. & $\mathrm{R}$ & & & & \\
\hline $\begin{array}{l}M \\
0\end{array}$ & $\mathrm{R}$ & Adjuste & $\begin{array}{l}\text { Error of } \\
\text { the }\end{array}$ & $\begin{array}{l}\text { Squar } \\
\mathrm{e}\end{array}$ & $\mathrm{F}$ & & & Sig. $F$ \\
\hline $\begin{array}{ll}\mathrm{d} & \\
\mathrm{el} & \mathrm{R}\end{array}$ & $\begin{array}{l}\text { Squ } \\
\text { are }\end{array}$ & $\begin{array}{l}\mathrm{d} \quad \mathrm{R} \\
\text { Square }\end{array}$ & $\begin{array}{l}\text { Estimat } \\
\mathrm{e}\end{array}$ & $\begin{array}{l}\text { Chang } \\
\text { e }\end{array}$ & $\begin{array}{l}\text { Cha } \\
\text { nge }\end{array}$ & $\begin{array}{l}\mathrm{df} \\
1\end{array}$ & $\begin{array}{l}\mathrm{df} \\
2\end{array}$ & $\begin{array}{l}\text { Chan } \\
\text { ge }\end{array}$ \\
\hline $1{ }^{a}$ & $\begin{array}{l}.66 \\
1\end{array}$ & .628 & .236 & .661 & $\begin{array}{l}20 . \\
444\end{array}$ & 4 & 42 & .000 \\
\hline
\end{tabular}

a. Predictors: (Constant), Brand Attitude and Behavior, Brand Identity, Brand Personality, Brand Association

b. Dependent Variable: Brand Image

Sumber : data primer

Pada tabel ANOVA di atas diperoleh nilai Fhitung = 20,444, nilai Fhitung akan dibandingkan dengan Ftabel. Nilai Ftabel dengan df1 $=4$ dan df2 $=42$ adalah 2,59 pada taraf $5 \%$ dan 3,80 pada taraf $1 \%$. Untuk mengambil keputusan didasarkan pada kriteria pengujian dibawah ini:

$\checkmark \quad$ Jika Fhitung < Ftabel maka H0 diterima

$\checkmark \quad$ Jika Fhitung $>$ Ftabel maka H0 ditolak

Berdasarkan penjelasan di atas maka 20,444 > 2,59 pada taraf $5 \%$ dan $3,80>7,44$ pada taraf $1 \%$, sehingga $\mathrm{H} 0$ ditolak artinya ada pengaruh yang signifikan antara dimensi brand image dengan brand image.

\section{Uji t-Statistik}

Uji $\mathrm{t}$ dilakukan untuk melihat pengaruh masingmasing variabel bebas secara sendiri-sendiri terhadap variabel terikat. Nilai t hitung kemudian dibandingkan dengan $t$ tabel.

Tabel 4.5. Output Uji t statistic SPSS 25 Coefficients $^{\mathbf{a}}$

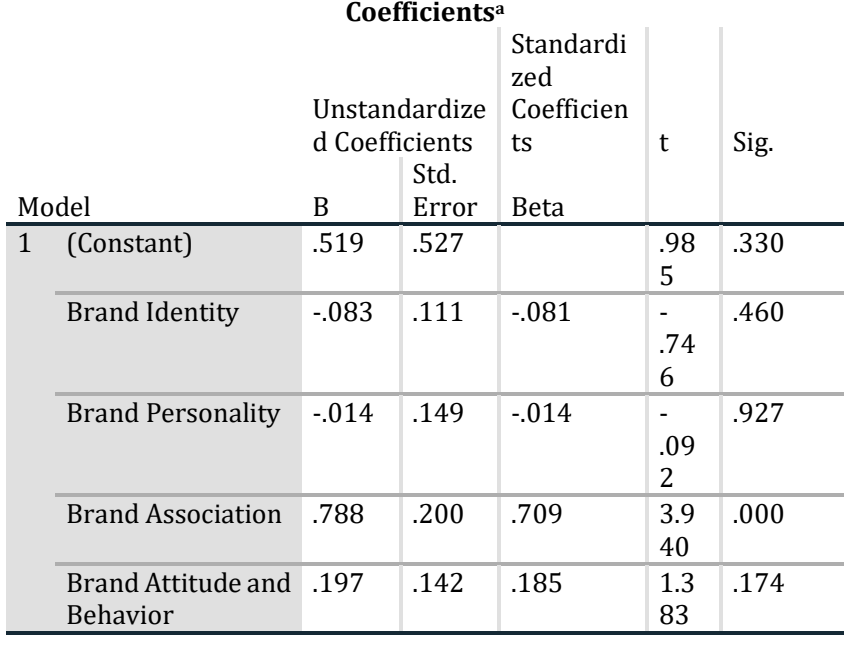

a. Dependent Variable: Brand Image Sumber : data primer

Dari hasil output SPSS 25, diketahui nilai t hitung dan sig. setiap variabel sebagai berikut.

Tabel 4.6. Output Uji t SPSS 25

\begin{tabular}{|l|l|l|l|}
\hline Variabel & $\begin{array}{l}\text { Nilai t } \\
\text { hitung }\end{array}$ & Sig. & Hasil \\
\hline $\begin{array}{l}\text { Brand } \\
\text { identity }\end{array}$ & 0,746 & 0,460 & $\begin{array}{l}\text { Tidak } \\
\text { berpengaruh } \\
\text { signifikan }\end{array}$ \\
\hline $\begin{array}{l}\text { Brand } \\
\text { personality }\end{array}$ & 0,092 & 0,927 & $\begin{array}{l}\text { Tidak } \\
\text { berpengaruh } \\
\text { signifikan }\end{array}$ \\
\hline $\begin{array}{l}\text { Brand } \\
\text { Assosiation }\end{array}$ & 3,940 & 0,000 & $\begin{array}{l}\text { Berpengaruh } \\
\text { signifikan }\end{array}$ \\
\hline $\begin{array}{l}\text { Brand } \\
\text { attitude and } \\
\text { behavior }\end{array}$ & 1,383 & 0,174 & $\begin{array}{l}\text { Tidak } \\
\text { berpengaruh } \\
\text { signifikan }\end{array}$ \\
\hline
\end{tabular}

Sumber : data primer

Dapat disimpulkan bahwa hanya variabel brand association yang berpengaruh signifikan terhadap brand image.

3. Koefesien Determinasi $\left(\mathrm{R}^{2}\right)$

Dari output di atas diperoleh nilai koefisian Determinasi atau R Square (r2) adalah 0,661. Jadi besar pengaruh dimensi brand image terhadap brand image adalah $66,1 \%$. Sisanya 33,9\% dipengaruhi oleh variabel-variabel lain yang belum dimasukkan dalam model.

Menurut Sugiyono pedoman untuk memberikan interpretasi koefisien korelasi sebagai berikut:

$0,00-0,199=$ sangat rendah

$0,20-0,399=$ rendah

$0,40-0,599=$ sedang

$0,60-0,799=$ kuat

$0,80-1,000=$ sangat kuat

Berdasarkan interpretasi koefisien korelasi di atas maka nilai $\mathrm{r} 2=0,661$ berada pada hubungan kuat sehingga dapat diambil kesimpulan bahwa dimensi brand image dengan brand image mempunyai hubungan yang kuat.

Untuk mengetahui apakah persamaan regresi di atas dapat digunakan untuk memprediksi atau meramalkan besarnya variabel kriterium (Y) berdasarkan variabel prediktor (X) dilakukan pengujian hipotesis untuk mengetahui signifikansi antara dua variabel. Untuk pengujian hipotesis menggunakan analisis regresi linier berganda, dibawah ini merupakan hasil analisis regresi linier sederhana.

Kesimpulan Uji hipotesis

Hipotesis dalam penelitian ini adalah

Hipotesis pertama

$\mathrm{HO}=$ Tidak ada pengaruh yang signifikan antara brand identity dengan brand image

H1 = Ada pengaruh yang signifikan antara brand identity dengan brand image 
Hasil olah data menunjukkan bahwa H0 diterima dan H1 ditolak

Hipotesis kedua

HO = Tidak ada pengaruh yang signifikan antara brand personality dengan brand image

$\mathrm{H} 1$ = Ada pengaruh yang signifikan antara brand personality dengan brand image

Hasil olah data menunjukkan bahwa H0 diterima dan H1 ditolak

Hipotesis ketiga

$\mathrm{HO}=$ Tidak ada pengaruh yang signifikan antara brand association dengan brand image

$\mathrm{H} 1$ = Ada pengaruh yang signifikan antara brand association dengan brand image

Hasil olah data menunjukkan bahwa H0 ditolak dan H1 diterima

Hipotesis keempat

$\mathrm{HO}=$ Tidak ada pengaruh yang signifikan antara brand attitude and behavior dengan brand image

$\mathrm{H} 1$ = Ada pengaruh yang signifikan antara brand attitude and behavior dengan brand image

Hasil olah data menunjukkan bahwa $\mathrm{HO}$ diterima dan H1 ditolak

\subsection{Pembahasan Hasil Analisis}

Pada bagian ini akan disajikan deskripsi data hasil penelitian terhadap variabel variabel penelitian. Data hasil penelitian berupa skor yang diambil dari hasil penyebaran angket, terhadap responden sebagai dasar untuk menganalisis lebih lanjut penelitian ini.

\subsubsection{Variabel Brand image $(\mathrm{Y})$}

Variabel citra merek ini merupakan representasi dari keseluruhan persepsi terhadap merek Kemenkeu Corpu yang dibentuk dari informasi dan pengetahuan terhadap merek itu, keyakinan dan preferensi terhadap merek dan apa yang peserta pelatihan pikirkan dan rasakan ketika mendengar atau melihat nama merek Kemenkeu Corpu. Persepsi terhadap citra merek ini dibentuk dari dimensi citra merek yang dijadikan sebagai variabel terikat dalam penelitian ini. Citra merek menyangkut reputasi dan kredibilitas merek, sebagai representasi dari keseluruhan persepsi terhadap merek sehingga konsumen yang memiliki citra positif terhadap merek akan lebih memungkinkan untuk melakukan pembelian (Aaker, 1991, Wijaya, 2011 dan Setiadi, 2003). Sejalan dengan Hung Hung, Chia (2008) menyebut efek langsung dari citra merek pada loyalitas pelanggan lebih kuat daripada persepsi hubungan masyarakat.

Pertanyaan pada variabel ini terkait dengan Kemenkeu Corpu adalah merek yang bagus dan terkenal, menwarkan berbagai jenis layanan pendidikan dan pelatihan, bermanfaat untuk pengembangan SDM Kemenkeu, dapat diandalkan untuk mendukung kinerja organisasi, menciptakan learning organization dan memberikan kesan positif/ berkelas bagi pelanggannya. Keberadaan suatu organisasi salah satunya tergantung dengan citra mereknya. BPPK sebagai unit yang memiliki tanggung jawab dalam pengembangan SDM pengelola keuangan dan kekayaan negara melalui penyelenggaraan pendidikan dan pelatihan. Oleh karena itu BPPK menetapkan visi "menjadi lembaga pendidikan dan pelatihan terkemuka yang menghasilkan pengelola keuangan negara berkelas dunia". Citra merek corporate university akan baik jika proses menuju kearah pencapaian visi tersebut sejalan dengan program dan kegiatannya.

\subsubsection{Variabel Brand identity (X1)}

Variabel identitas merek Kemenkeu Corpu ditunjukkan dengan adanya logo, rumah Corpu, penyamaan Corpu dengan BPPK dan ciri khas sebagai lembaga training yang khas. Berdasarkan persamaan regresi penelitian, variabel identitas merek memiliki koefisien sebesar -0,014. Besar koefisien tersebut menandakan bahwa hubungan variabel ini sangat rendah membentuk citra merek. Hal ini bertentangan dengan hasil peneltian Yanu (2014) dan Indra Cahyani (2016) menunjukkan bahwa identitas merek berperan dalam keputusan pembelian konsumen namun beriringan dengan penelitian Shirazil, Ali. et all., (2013) dan Tamimi (2013) bahwa identitas merek memiliki pengaruh tidak langsung pada loyalitas merek melalui nilai yang dirasakan, kepercayaan, dan kepuasan.

Pada penelusuran pustaka yaitu Keputusan Menteri Keuangan 563/KMK.011/2017 tentang Logo Kementerian Keuangan Corporate University, logo Kemenkeu Corpu khas dengan warna yang khas. Logo tersebut berdasarkan pengamatan peneliti sudah dipasang di spanduk, bahan tayang di kelas, tayangan pengarahan program pelatihan. Namun sebagian besar responden belum memahami makna logo tersebut. Berdasarkan wawancara dengan responden, mereka mengakui bahwa logo Kemenkeu Corpu menarik, mudah diingat, warna yang bagus. Terkait rumah Corpu, sebagian besar responden belum mengenai konsep tersebut.

Kecilnya koefisien identitas merek ini $(0,083)$ menunjukkan bahwa responden tidak menganggap bahwa identitas ini sebagai factor kunci dihubungkan dengan citra merek. Pada domain birokrasi pemerintahan, logo kurang menjadi faktor kunci sebuah merek. Berbeda dengan perusahaan swasta yang berusaha membuat logo yang menarik karena hal itu akan meningkatkan penjualan mereka.

Koefisien identitas merek ini bertanda negatif, artinya jika variabel lainnya tetap dan identitas merek mengalami kenaikan 1\%, maka citra merek akan mengalami penurunan sebesar 0,083\%. Koefisien bernilai negatif artinya terjadi hubungan negatif antara identitas merek dengan citra merek. Semakin naik identitas merek maka semakin turun citra merek. 


\subsubsection{Variabel Brand personality (X2)}

Brand personality berhubungan dengan karakter khas Kemenkeu Corpu yang membentuk kepribadian tertentu sebagaimana layaknya manusia. Pertanyaan yang diajukan terkait dengan kepribadian yang menyenangkan, kesan professional, inovatif, mempesona, membuat bergengsi penggunanya, tegas, anggun dan serius. Tamimi, Hoda. et all (2016) menunjukkan bahwa kepribadian merek yang hangat memiliki dampak positif pada identitas merek konsumen

Pada saat pendalaman konsep personality, responden belum melihat personalitas tersebut. Peserta pelatihan mengalami, mengamati dan mendengar merek Corpu selama berada di lingkungan BPPK. Diluar itu, mereka tidak mengikuti perkembangan pembelajaran. Sehingga kepribadian merek ini tidak begitu dirasakan.

Koefisien kepribadian merek bernilai 0,014. Kecilnya koefisien ini menunjukkan bahwa responden tidak menganggap bahwa identitas ini sebagai factor kunci dihubungkan dengan citra merek. Koefisien identitas merek ini bertanda negatif, artinya jika variabel lainnya tetap dan identitas merek mengalami kenaikan 1\%, maka citra merek akan mengalami penurunan sebesar 0,014\%. Koefisien bernilai negatif artinya terjadi hubungan negatif antara personalitas merek dengan citra merek. Semakin naik personalitas merek maka semakin turun citra merek.

\subsubsection{Variabel Brand association (X3)}

Variabel asosiasi merek terkait dengan hal-hal spesifik yang pantas atau selalu dikaitkan dengan suatu merek Kemenkeu Corpu, yang muncul dari keunikan suatu produk, aktivitas yang berulang dan konsisten. Ingat pelatihan ingat BPPK. Pertanyaan berhubungan dengan Kemenkeu Corpu berbeda dengan training center biasa, tempat yang nyaman untuk pelatihan, tetap mengingat Corpu, pemanfaatan teknologi, sesuai kebutuhan, mudah diakses, memperkuat performance.

Koefisien asosiasi merek bernilai 0,788. Besar koefisien ini menunjukkan bahwa responden menganggap bahwa asosiasi merek sebagai faktor kunci dihubungkan dengan citra merek. Hubungan antara asosiasi merek dan citra merek sangat kuat. Jika variabel lainnya tetap dan asosiasi merek mengalami kenaikan 1\%, maka citra merek akan mengalami kenaikan sebesar 0,788\%.

Hal ini sejalan dengan penelitian Wasil (2017) bahwa asosiasi merek mempengahi keputusan pembelian. Berdasarkan studi pustaka, proses bisnis BPPK dikelompokkan menjadi tiga jenis. Pertama proses inti, yaitu proses yang meliputi bisnis inti dan menciptakan aliran nilai utama atas penyelenggaraan tugas dan fungsi BPPK meliputi pendidikan, pelatihan, sertifikasi, knowledge management system (KMS), dan learning management system (LMS). Kedua proses manajemen, yaitu proses yang mengcndalikan atau mengelola operasional dari suatu sistem, atau proses yang memastikan proses inti/operasional dan proses pendukung berjalan dengan baik, terdiri dari pengelolaan kinerja, penjaminan mutu, kepatuhan internal, manajemen risiko, perencanaan strategis, serta humas dan publikasi. Dan ketiga proses pendukung, yaitu proses yang mendukung proses inti, terdiri dari penelitian, hukum, organisasi dan tata laksana, kepegawaian, keuangan, pengelolaan BMN, dan sistem informasi.

Responden menganggap bahwa asosiasi merek ini sangat mereka rasakan. Berdasarkan wawancara, responden merasa ada perbedaan saat mengikuti pelatihan sekarang, baik sebelum pelatihan yaitu saat registrasi, situasi pembelajaran di kelas, sarana prasarana yang ada sampai dengan evaluasi pelatihan.

Koefisien asosiasi merek ini bertanda positif, artinya jika variabel lainnya tetap dan asosiasi merek mengalami kenaikan 1\%, maka citra merek juga akan mengalami kenaikan sebesar 0,788\%. Koefisien bernilai positif artinya terjadi hubungan positif antara asosiasi merek dengan citra merek. Semakin naik asosiasi merek maka semakin meningkat citra merek.

\subsubsection{Variabel Brand attitude and behavior (X4)}

Sikap terhadap merek berhubungan dengan sikap atau perilaku komunikasi dan interaksi merek Kemenkeu Corpu dengan stakeholder dalam menawarkan benefit-benefit pelatihan dan nilai yang dimilikinya. Variabel ini berhubungan dengan sikap positif terhadap Kemenkeu Corpu, berkualitas bagus, senang dan respek dengan Kemenkeu Corpu. Salehzadeh (2017) menyebutkan bahwa sikap merek secara positif mempengaruhi nilai yang dirasakan

Koefisien sikap terhadap merek bernilai 0,197. Besar koefisien ini menunjukkan bahwa responden menganggap bahwa sikap terhadap merek sebagai faktor pendukung dihubungkan dengan citra merek. Hubungan antara sikap terhadap merek dan citra merek sangat rendah. Jika variabel lainnya tetap dan sikap terhadap merek mengalami kenaikan 1\%, maka citra merek akan mengalami kenaikan sebesar $0,197 \%$.

Responden menganggap bahwa sikap merek ini mereka rasakan namun belum optimal. Berdasarkan wawancara, responden merasa bahwa pelatihan mendukung kinerja di kantor, kualitasnya masih bisa ditingkatkan, senang mengikuti pelatihan di BPPK walaupun ada beberapa faktor yang belum maksimal misalnya sarana prasarana. Ada perbedaan sarana prasarana di setiap puspelatihan dan balai pelatihan. Walaupun sudah ada peraturan tentang standar sarana prasarana, namun perbedaan itu ada karena sudah ada kegiatan pengadaan sebelum peraturan muncul, misalnya ada televisi di kamar asrama, ketersediaan air panas dingin di kamar mandi dan lain-lain. 
Koefisien sikap merek ini bertanda positif, artinya jika variabel lainnya tetap dan sikap merek mengalami kenaikan $1 \%$, maka citra merek juga akan mengalami kenaikan sebesar 0,197\%. Koefisien bernilai positif artinya terjadi hubungan positif antara sikap merek dengan citra merek. Semakin naik sikap merek maka semakin meningkat citra merek.

\subsubsection{Variabel persepsi pengguna Kemenkeu Corpu}

Analisis untuk variabel persepsi pengguna menggunakan analisis kualitatif deskriptif. Instrumen yang digunakan adalah wawancara dan studi kepustakaan. Responden memiliki persepsi bagus terhadap Kemenkeu Corpu. Di satu sisi, responden belum meyakini benar bahwa pelatihan yang diikuti mampu meningkatkan performa di kantor. Pada pelatihan teknis tertentu dimana peserta pelatihan baru menduduki jabatan teknis, misalnya Pejabat Pembuat Komitmen (PPK), Pejabat Penandatangan Surat Perintah Membayar (PPSPM), Kuasa Pengguna Anggaran (KPA), responden sangat antusias dan memberikan pernyataan bahwa pelatihan sangat bermanfaat bagi mereka. Hal ini sesuai dengan konsep Schiffman \& Kanuk (2008).

Secara keseluruhan jika dibandingkan antara sebelum dan sesudah Corpu, responden mengakui bahwa BPPK sangat banyak berbenah terkait pembelajaran. Mereka dapat belajar kapan saja dan dimana saja karena sudah disediakan tools pembelajaran di Kemenkeu Learning Center yang tersedia online di www.klc.kemenkeu.go.id.

Penyediaan smart class room juga diakui oleh responden sebagai terobosan baru dalam pembelajaran. Berdasarkan Keputusan Kepala Badan Pendidikan Dan Pelatlhan Keuangan Nomor Kep148/PP/ 2017 Tentang Pedoman Standar Ruang Kelas Pintar (Smart Classroom) di Lingkungan Badan Pendidikan Dan Pelatihan Keuangan, smart classroom ini ditujukan untuk meningkatkan kolaborasi dan interaksi antara pengajar dengan peserta, dan antar peserta dalam proses pembelajaran, merupakan strategi transformatif dari pembelajaran tradisional ke pembelajaran digital yang bermakna, menarik, dan terhubung, memungkinkan peserta pembelajaran untuk mengakses sumber-sumber digital dan berinteraksi dengan sistem pembelajaran di mana saja dan kapan saja.

Corporate University didefinisikan sebagai strategi yang digunakan untuk mencapai visi dan misi Kementerian Keuangan, dengan mewujudkan link and match antara pembelajaran, pengelolaan pengetahuan, dan penerapan nilai-nilai dengan target kinerja Kementerian Keuangan dan dilaksanakan oleh seluruh elemen Kementerian Keuangan dengan BPPK sebagai motor penggerak utama bagi SDM Keuangan Negara. Corporate University bertanggung jawab dalam pengembangan SDM serta peningkatan kapabilitas dan daya saing organisasi, sehingga
Corporate University harus mampu go beyond training and development dalam memastikan bahwa ilmu yang didapatkan dapat diimplementasikan dan memiliki link and match dengan target kinerja Kementerian Keuangan. Proses bisnis pengembangan SDM yang lebih aplikatif, relevan/adaptif, mudah diakses, dan berdampak tinggi.

\section{KESIMPULAN}

Berdasarkan hasil penelitian dan pembahasan, didapatkan kesimpulan yang sesuai dengan rumusan masalah dalam penelitian yaitu sebagai berikut:

1. Tidak terdapat pengaruh yang signifikan antara brand identity dengan brand image Kemenkeu Corpu. Variabel identitas merek tidak berpengaruh signifikan terhadap citra merek. Maka identitas berupa logo Corpu tetap seperti semula atau berubah tidak akan banyak berpengaruh terhadap persepsi pengguna Corpu.

2. Tidak terdapat pengaruh yang signifikan antara brand personality dengan brand image Kemenkeu Corpu. Variabel kepribadian merek tidak berpengaruh signifikan terhadap citra merek. Bagaimana BPPK merumuskan nama "Kemenkeu Corpu", mengemas konsep Corpu tidak banyak berpengaruh terhadap persepsi pengguna Corpu.

3. Terdapat pengaruh yang signifikan antara brand association dengan brand image Kemenkeu Corpu. Variabel asosiasi merek berupa nilai-nilai representasi bukan lembaga training biasa berpengaruh signifikan terhadap citra merek.

4. Tidak terdapat pengaruh yang signifikan antara brand attitude and behavior dengan brand image Kemenkeu Corpu. Interaksi konsep Corpu dengan pengguna tidak terlalu berpengaruh terhadap persepsi pengguna.

5. Secara keseluruhan terdapat pengaruh yang signifikan antara dimensi brand image dengan brand image. Besar pengaruh dimensi brand image dengan brand image dilihat dari koefisien determinasi yaitu sebesar 66,1\%. Sisanya 33,9\% dipengaruhi oleh variabel-variabel lain yang belum dimasukkan dalam model.

6. Terdapat pengaruh brand image Kemenkeu Corpu terhadap persepsi konsumen. Responden menganggap bahwa citra merek yang kuat terutama terkait dengan asosiasi merek dengan citra merek. Pengguna Kemenkeu Corpu menyatakan bahwa kemudahan dan pelayanan yang tinggi pada saat mengikuti pelatihan dapat membuat mereka merasa nyaman. Pelatihan di Kemenkeu Corpu dipersepsikan bagus karena dapat meningkatkan performa mereka di tempat kerja.

\section{IMPLIKASI DAN KETERBATASAN}

\subsection{Implikasi}

Berdasarkan hasil penelitian dan pembahasan, saran yang dapat digali adalah sebagai berikut: 
1. ВPPK

BPPK diharapkan dapat menyampaikan sosialisasi Kemenkeu Corpu secara masif kepada semua stakeholdernya. Sosialisasi ini bisa dilakukan melalui brosur, media sosial, pertemuan rutin dengan eselon satu lain maupun melalui pelatihan yang diselenggarakan. Pengguna Kemenkeu Corpu akan memahami arah strategi pembelajaran yang diterapkan oeh BPPK sekarang dan memberikan kesediaan untuk turut berperan serta dalam peningkatan kualitas Kementerian Corpu. BPPK juga dapat berfokus pada faktor asosiasi merek karena mendapatkan koefisien yang paling tinggi diantara dimensi ditra merek yang lain. Cara yang dapat dilakukan adalah dengan meningkatkan pelayanan kepada peserta pelatihan baik mulai dari input, proses maupun pelatihan pelatihan.

2. Peserta Pelatihan

Peserta pelatihan di BPPK agar mengikuti proses pembelajaran Kemenkeu Corpu dengan sebaikbaiknya, baik sebelum berangkat pelatihan, selama dan setelah selesai mengikuti pelatihan. Melalui konsep 70-20-10, dimana faktor klasikal (tatap muka di kelas, hanya memberikan dampak peningkatan kinerja sebesar 10\%), coaching mentoring, community of practice dan action learning memberikan dampak 20\% kepada peningkatan kinerja dan $70 \%$ faktor penugasan di tempat kerja, on the job training, rotasi, mutase. Perubahan kesadaran (pola pikir) mengenai pelatihan ini yang harus ditanamkan sehingga peran individu peserta pelatihan sangat besar menuju peningkatan kinerja.

3. Peneliti selanjutnya

Peneliti selanjutnya dapat melakukan penelitian berikutnya dengan menambahkan variabel lain yang berhubungan dengan dimensi merek dan citra merek. Selain itu pendekatan metodologi penelitian yang berbeda dapat memperkaya khazanah keilmuan terkait Kemenkeu Corpu.

\subsection{Keterbatasan Penelitian}

Informasi dari hasil penelitian dapat dijadikan sebagai pertimbangan pengambilan keputusan pengembangan Kemenkeu Corpu. Sebelum digunakan untuk kepentingan tersebut, perlu diketahui bahwa penelitian ini memiliki keterbatasan antara lain:

1. Variabel dibatasi yaitu brand identity, brand personality, brand association dan brand attitude and behavior sebagai variabel bebas yang mempengaruhi brand image. Dalam konsep merek, tidak hanya empat variabel bebas ini saja sebagai dimensi citra merek, tetapi masih ada variabel lainnya yang belum diungkap yaitu brand benefit and competence.

2. Ditinjau dari metodologinya, penelitian ini menggunakan pendekatan kuantitatif dan kualitatif untuk variabel yang berbeda. Pada pengujian variabel bebas dimensi citra merek tidak dilengkapi dengan pendekatan kualitatif untuk memperdalah kajian. Pada segi instrumen, dapat ditambahkan komponen lain yang belum diperhitungkan.

3. Jawaban yang diberikan oleh responden tidak dapat dikontrol. Para responden mungkin saja memberikan jawaban yang tidak sesuai dengan keadaan yang sebenarnya, atau jawaban yang mereka berikan dibuat asal jadi tanpa memikirkannya terlebih dahulu. Ini dapat terjadi bila terdapat faktor yang bersifat psikologis dari para responden yang kurang stabil maupun keterbatasan waktu responden. Kondisi ini memengaruhi analisis data, akhirnya berpengaruh pada temuan penelitain.

4. Dengan keterbatasan-keterbatasan tersebut diharapkan membuka peluang pada penelitian lanjutan untuk mengkaji faktor lain selain yang dimasukkan dalam penelitian ini yang terkait dengan brand image dan persepsi pengguna Kemeneku Corpu yang belum diungkap dan dibahas dalam penelitian ini.

\section{DAFTAR PUSTAKA}

Aaker, Jennifer L. (1997). Dimensions Of Brand Personality. Journal of Marketing Research. Vol. 34, No. 3 (Aug., 1997), Pp. 347-356. Published By: American Marketing Associa

Armawati, Isna, Saryadi Dan Prabawani, Bulan (Tanpa Tahun). Pengaruh Brand Awareness, Brand Image dan Perceived Quality terhadap Keputusan Pemakaian Jasa pada Maskapai Penerbangan Garuda Indonesia. Jurnal Ilmu Administrasi Bisnis Jurusan Ilmu Administrasi Bisnis. Universitas Diponegoro.

Arnold, David. (1996). Pedoman Manajemen Merek. Kentindo Soho. Surabaya.

Indra Cahyani, Khoiriyah dan Sutrasmawati, Rr. Endang. (2016). Pengaruh Brand Awareness Dan Brand Image Terhadap Keputusan Pembelian. Management Analysis Journal 5 (4) (2016). http://Maj.Unnes.Ac.Id.

Karam, A.A., \& Saydam, S. (2015). An Analysis Study of Improving Brand Awareness And Its Impact On Consumer Behavior Via Media In North Cyprus (A Case Study of Fast Food Restaurants). International Journal of Business And Social Science Vol. 6, No. 1; January 2015

Kasali, Rhenald. 2016. Let's Change.Penerbit Kompas. Jakarta.

Kotler, Philip Dan Keller, Kevin Lane. Manajemen Pemasaran, Edisi 12, PT Indeks, Jakarta

Kurnia, Eddy. (2013). Customer Is Change. Bukurepublika.

Lindeberg, Manda. Et Al. (2012). Understanding The Relationship Etween Brand Identity And Brand Image. A Case Study of Coop. Linnaeus University. Bachelor Thesis Spring Semester 2012 
Mowen, John C dan Minor, Michael. (2002). Perilaku Konsumen Jilid Satu Edisi Lima. Erlangga. Jakarta

Orlando, Dillon (2015). Analisa Pengaruh Brand Image Dan Brand Awareness Terhadap Purchase Intention Sepeda Motor " Kawasaki Ninja 250Fi “Jurnal Managemen Pemasaran Petra Vol . 3, No. 1, (2015) 1-9

Rachmawati, Ike Kusdiyah. (2008). Manajemen Sumber Daya Manusia. Penerbit Andi. Yogyakarta.

Rademakers, F Martyn .(2017).Corporate University. Penerbit PPM. Jakarta

Rahardjo, Toto Dan Farida, Siti (Tanpa Tahun). Analisis Atribut Brand Association (Asosiasi Merek) Telepon Seluler Nokia (Studi Kasus Pada Mahasiswa Fakultas Ekonomi Universitas Brawijaya). Fakultas Ekonomi UKWN Surabaya

Rosengren, Alexandra. (2010). Brand Identity \& Brand Image A Case Study of Apotek Hjärtat. Jönköping University

Salehzadeh, Reza \& Khazaei Pool, Javad (2017) Brand Attitude and Perceived Value and Purchase Intention toward Global Luxury Brands, Journal of International Consumer Marketing, 29:2, 7482, DOI: $10.1080 / 08961530.2016 .1236311$

Setiadi, Nugroho J. (2008). Perilaku Konsumen :Konsep Dan Impilikasi Untuk Strategi Dan Penelitian Pemasaran. Kencana Jakarta

Shirazil, Ali. Et Al (2013) Investigating The Effects of Brand Identity On Customer Loyalty From Social Identity Perspective. Iranian Journal of Management Studies (IJMS). Vol.6, No.2, July 2013. Pp: $153-178$

Sitinjak, Tony. Et Al. (2004). Model Matrik Konsumen Untuk Menciptakan Superior Customer Value. PT Gramedia Pustaka Utama. Jakarta
Sukma Wijaya, Bambang (2013). Dimensions Of Brand Image: A Conceptual Review From The Perspective of Brand Communication. European Journal of Business And Management. ISSN 2222-1905 (Paper) ISSN 2222-2839 (Online). Vol 5, No.31, 2013

Tamimi, Hoda. Et Al (2016). The Relationship Between Consumer Identity And Brand Identity of Toyota In Abadan And Khorramshahr City. International Journal of Humanities And Cultural Studies ISSN 2356-5926. Special Issue January 2016

Wasil, Mohammad (2017). Pengaruh Brand Awareness, Brand Association, dan Percieved Quality. FORUM EKONOMI. Volume 19 (2), 2017.

Http://journal.feb.unmul.ac.id/index.php/FO RUMEKONOMI

Yanu Alif Fianto, Achmad. Et Al. (2014). The Influence Of Brand Image On Purchase Behaviour Through Brand Trust. Business Management And Strategy ISSN 2157-6068. 2014, Vol. 5, No. 2

Https://www.Gomarketingstrategic.Com/2016/06/P engertian-Konsep-Fungsi-Dan-Tipe-Brand.Html http://shiftindonesia.com/8-langkah-perubahankotter/

Republik Indonesia, Keputusan Menteri Keuangan 563/KMK.011/2017 tentang Logo Kementerian Keuangan Corporate University Keputusan Kepala Badan Pendidikan Dan Pelatlhan Keuangan Nomor Kep- 148/PP/ 2017 Tentang Pedoman Standar Ruang Kelas Pintar (Smart Classroom Di Lingkungan Badan Pendidikan Dan Pelatihan Keuangan 